5. Poiret $T$, Axelsson-Robertson R, Remberger M, Luo XH, Rao M, Nagchowdhury A, Von Landenberg A, Ernberg I, Ringden 0, Maeurer M. Cytomegalovirusspecific CD8+ T-cells with different T-cell receptor affinities segregate T-cell phenotypes and correlate with chronic graft-versus-host disease in patients post-hematopoietic stem cell transplantation. Front Immunol 2018;9:760.

6. Tzannou I, Papadopoulou A, Naik S, Leung K, Martinez CA, Ramos CA, Carrum G, Sasa G, Lulla P, Watanabe A, Kuvalekar M, Gee AP, Wu MF, Liu H, Grilley BJ, Krance RA, Gottschalk S, Brenner MK, Rooney CM, Heslop
HE, Leen AM, Omer B. Off-the-shelf virus-specific T cells to treat BK virus, human herpesvirus 6, cytomegalovirus, Epstein-Barr virus, and adenovirus infections after allogeneic hematopoietic stem-cell transplantation. J Clin Oncol 2017;35:3547-3557.

\title{
Comparison of Different Culture Conditions for Mesenchymal Stem Cells from Human Umbilical Cord Wharton's Jelly for Stem Cell Therapy
}

\author{
Kök Hücre Tedavisi için Insan Kordon Kanı Wharton Jel'inden Üretilen Mezenkimal Kök \\ Hücreler için Farkı Kültür Ortamlarının Karşılaştırılması
}

\author{
(D) Yu Bao1, (D) Shumin Huang2 ${ }^{2}$ (D) Zhengyan Zhao² \\ 1Zhejiang University Faculty of Medicine, Children's Hospital, Department of Nephrology, Zhejiang, China \\ 2Zhejiang University Faculty of Medicine, Children's Hospital, Clinic of Division of Child Health Care, Zhejiang, China
}

To the Editor,

Many recent studies have demonstrated that the umbilical cord is an excellent source of mesenchymal stem cells (MSCs) $[1,2,3]$. However, in order to use human umbilical cord Wharton's jellyderived mesenchymal stem cells (hUC-MSCs) in clinical therapy, a suitable culture procedure for good manufacturing practicecompliant production is mandatory. Nutritional deficiency is the major pathophysiological situation in an ischemic microenvironment in the clinic [4]. Thus, the development of serum-free culture systems is needed [5]. Furthermore, hypoxia is common in vivo in mammals [6]. The average oxygen tension falls to $1 \%$ in some cases of pathological ischemia, including fracture hematoma, and in cases of myocardial ischemia [7]. Hence, the investigation of biological characteristics of hUCMSCs exposed to hypoxic and/or serum-free conditions is of great interest.

In our study, we conducted parallel assays by using four cell groups. For the hypoxic controls, cells from group $A(n=10)$ and group $B(n=10)$ were exposed to $5 \% \mathrm{CO}_{2}$ and $94 \% \mathrm{~N}_{2}$ in an airtight modular incubator chamber (Billups-Rothenberg Inc., Del Mar, CA, USA). The final oxygen tension was 1\%-3\% as measured by an oximeter (Oxybaby $\mathrm{M}+$, Witt Technology, Solza, Italy). For the normoxic controls, cells from group $\mathrm{C}(\mathrm{n}=10)$ and group $\mathrm{D}(\mathrm{n}=10)$ were placed in an incubator at $37^{\circ} \mathrm{C}, 5 \% \mathrm{CO}_{2^{\prime}}$ and $21 \% \mathrm{O}_{2}$. Cells from group $\mathrm{A}$ and group $\mathrm{C}$ were expanded in a mixture of Dulbecco's modified Eagle's medium and nutrient mixture F-12 (GIBCO, USA) supplemented with 10\% fetal bovine serum (GIBCO, USA). Cells from group $B$ and group D were expanded in StemPRO MSC serum-free medium (StemRD, USA). Flow cytometric analysis, differentiation potential, proliferative activities, cell cycle analysis, and apoptosis analysis of these four cell populations were evaluated. We repeated all these experiments 3 times.

Flow cytometry analysis of MSC-specific surface marker expression showed that hUC-MSCs cultured under four experimental conditions for six passages were positive for CD44, CD73, CD90, CD105, CD29, and HLA-ABC (BD Pharmingen, USA) and negative for CD34, CD45, CD14, and HLA-DR (BD Pharmingen, USA); no significant differences were detected between the four cell populations (Figure 1). This finding indicates that culturing cells under hypoxic and/or serum-free conditions did not induce significant variations in the typical MSC marker expression profile. hUC- 
MSCs maintained their multilineage differentiation potential in vitro after expansion under various conditions [8]. MSCs from all groups demonstrated a similar osteogenic phenotype, as evidenced by positive staining for alizarin red S (SigmaAldrich, USA) and deposits of calcified matrix (Figure 2). In the case of adipogenic differentiation, cells from all groups formed lipid vacuoles detected by oil red 0 (Sigma-Aldrich,
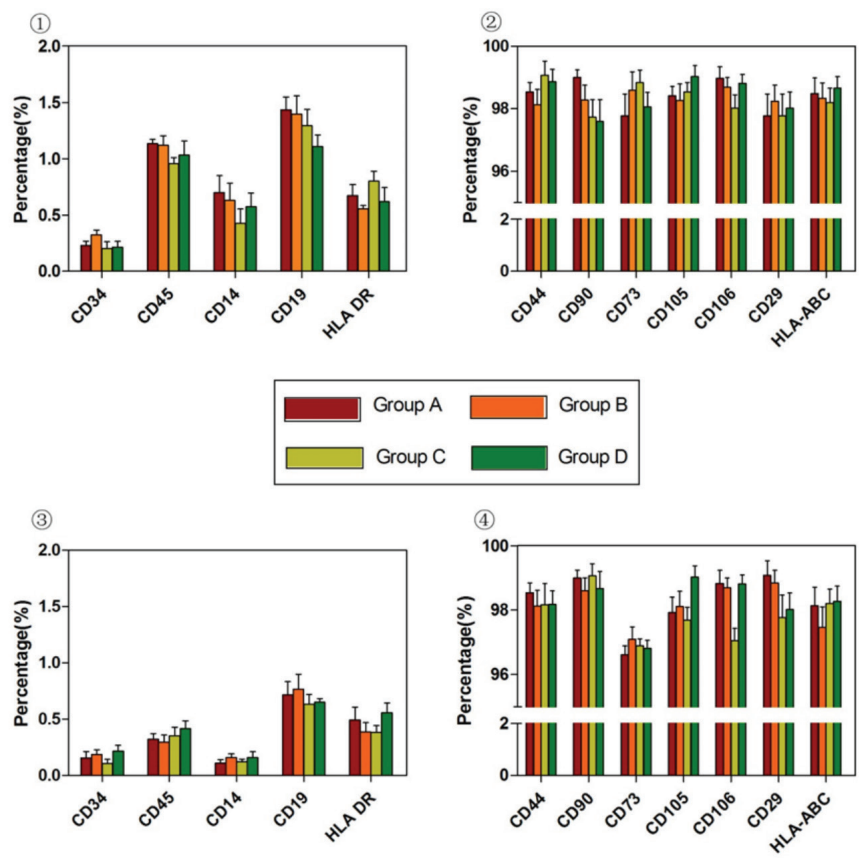

Figure 1. Flow cytometry of hUC-MSC samples [mean percentage \pm SD (\%)]. 1 and 2: Passage 3; 3 and 4: Passage 6.

SD: Standard deviation, hUC-MSC: Human umbilical cord Wharton's jelly-derived mesenchymal stem cells.
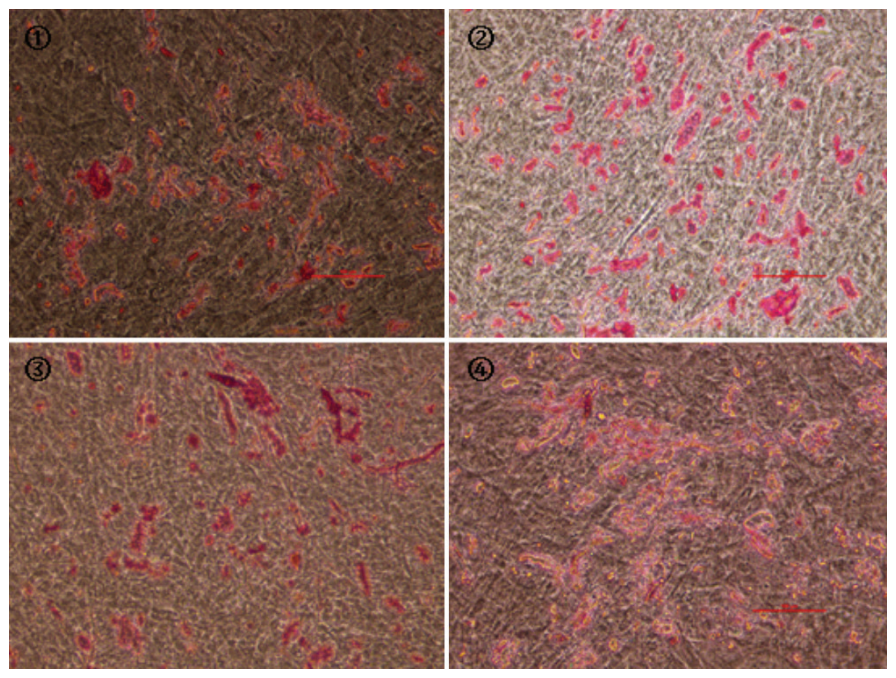

Figure 2. Multilineage differentiation potential of hUC-MSCs. Formation of mineralized matrix was detected by alizarin red $\mathrm{S}$ staining. 1: Group A; 2: Group B; 3: Group C; 4: Group D (original magnification: 200x, bar: $50 \mu \mathrm{m}$ ).

hUC-MSC: Human umbilical cord Wharton's jelly-derived mesenchymal stem cells.
USA). There were no significant quantitative changes among the groups (Figure 3). Thus, the results presented in this report indicate that hypoxic and/or serum-free conditions do not affect the biological characteristics of hUC-MSCs. Under hypoxic and serum-free conditions, hUC-MSCs have higher proliferation according to their growth curves (BD Pharmingen, USA) and MTT assays (BD Pharmingen, USA) than cells grown under normoxic and serum-containing culture conditions, but without more apoptosis (Figures 4 and 5).
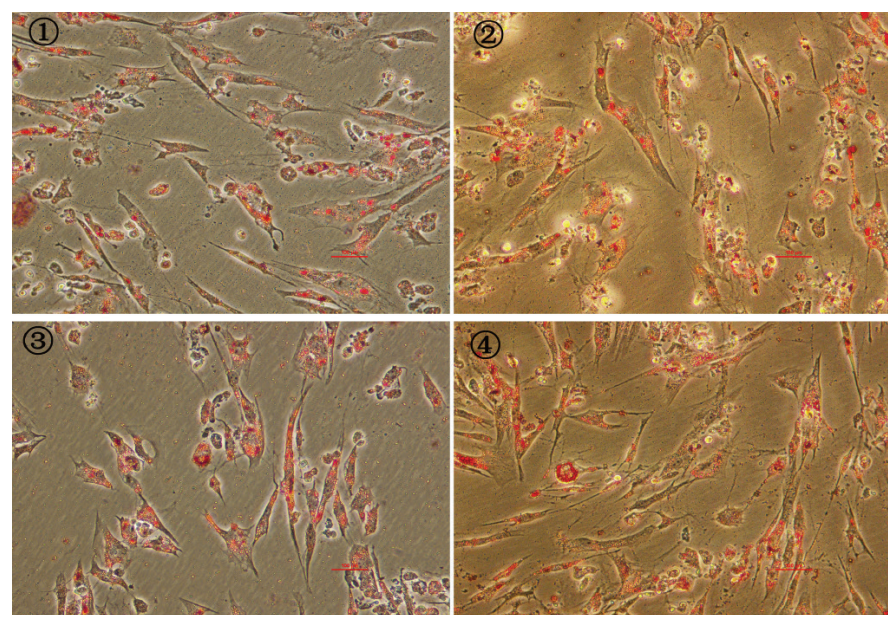

Figure 3. Multilineage differentiation potential of hUC-MSCs. Adipogenesis was confirmed by neutral oil droplet formation stained with oil red 0. 1: Group A; 2: Group B; 3: Group C; 4: Group D (original magnification: 100x, bar: $50 \mu \mathrm{m}$ ).

hUC-MSC: Human umbilical cord Wharton's jelly-derived mesenchymal stem cells.
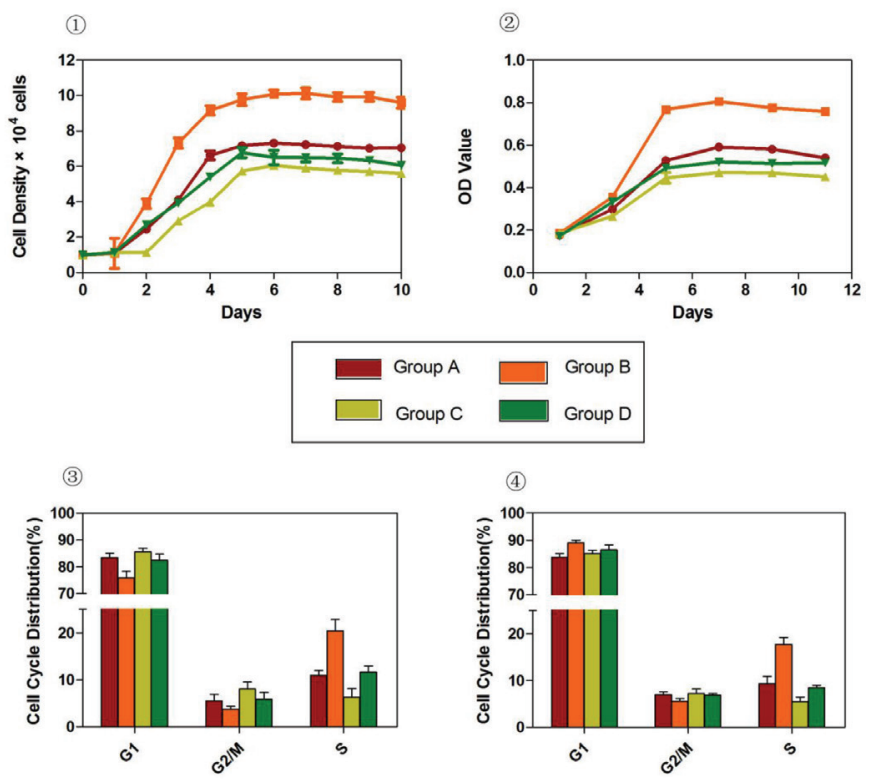

Figure 4. Expansion ability of the four groups. 1: Growth curve at passage 3. 2: MT assay at passage 3. 3: Cell cycle distribution at passage 3 [mean percentage $\pm \mathrm{SD}(\%)$ ]. 4 : Cell cycle distribution at passage 6 [mean percentage \pm SD (\%)].

SD: Standard deviation. 


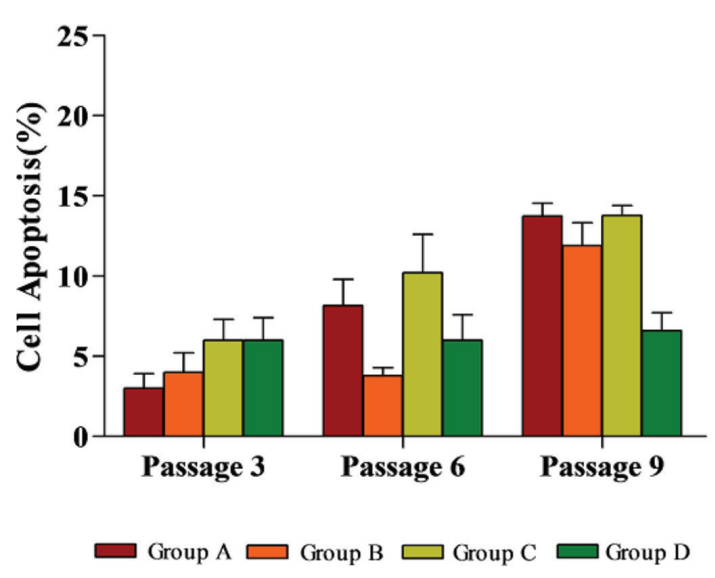

Figure 5. Proportion of apoptotic hUC-MSCs cultured under different conditions (mean \pm SD).

SD: Standard deviation, hUC-MSC: Human umbilical cord Wharton's jelly-derived mesenchymal stem cells.

Taken together, our data indicate that hypoxic and serum-free culture conditions do not influence the major properties of hUC-MSCs. Under hypoxic and serum-free conditions, hUCMSCs showed higher proliferation, while their apoptosis rate did not increase. This finding is consistent with that of previous reports, which demonstrated enhanced proliferation of bone marrow-derived MSCs (BM-MSCs) under hypoxic or serumfree conditions $[9,10]$. Therefore, the availability of optimized in vitro conditions, including hypoxia and serum-free media, for hUC-MSC manipulations may have a substantial scientific and clinical impact.

Funding: This work was funded by the Zhejiang Provincial Natural Science Foundation of China (Grant No. LY18H070001).

Ethics Committee Approval: All procedures performed in studies involving human participants were in accordance with the ethical standards of the Medical Ethics Committee of the Children's Hospital School of Medicine, Zhejiang University (reference number 1712048) and with the 1964 Helsinki Declaration and its later amendments or comparable ethical standards.

Informed Consent: Informed consent was obtained from all individual participants included in the study.

\section{Authorship Contributions}

Data collection or Processing: Y.B., S.H., Z.Z.; Analyses or Interpretration: Y.B., S.H., Z.Z.; Literature Search: Y.B., S.H., Z.Z.; Writing: Y.B., S.H., Z.Z.

Conflict of Interest: The authors of this paper have no conflicts of interest, including specific financial interests, relationships, and/or affiliations relevant to the subject matter or materials included.

Financial Disclosure: The authors declared that this study received no financial support.

\section{References}

1. Jin HJ, Bae YK, Kim M, Kwon SJ, Jeon HB, Choi SJ, Kim SW, Yang YS, Oh W, Chang JW. Comparative analysis of human mesenchymal stem cells from bone marrow, adipose tissue, and umbilical cord blood as sources of cell therapy. Int J Mol Sci 2013;14:17986-8001.

2. Mahla RS. Stem cells applications in regenerative medicine and disease therapeutics. Int J Cell Biol 2016;2016:6940283.

3. Chen $S$, Zhang $W$, Wang JM, Duan HT, Kong JH, Wang YX, Dong M, Bi X, Song J. Differentiation of isolated human umbilical cord mesenchymal stem cells into neural stem cells. Int J Ophthalmol 2016;9:41-47.

4. Lu HH, Li YF, Sheng ZQ, Wang Y. Preconditioning of stem cells for the treatment of myocardial infarction. Chin Med J (Engl) 2012;125:378-384.

5. Chang Z, Hou T, Xing J, Wu X, Jin H, Li Z, Deng M, Xie Z, Xu J. Umbilical cord Wharton's jelly repeated culture system: a new device and method for obtaining abundant mesenchymal stem cells for bone tissue engineering. PLoS One 2014;9:e110764.

6. Swamynathan P, Venugopal P, Kannan S, Thej C, Kolkundar U, Bhagwat S, Ta M, Majumdar AS, Balasubramanian S. Are serum-free and xeno-free culture conditions ideal for large scale clinical grade expansion of Wharton's jelly derived mesenchymal stem cells? A comparative study. Stem Cell Res Ther 2014;5:88.

7. Huang $Y$, Chen $B$, Zhang J. Oxygen tension variation in ischemic gastrocnemius muscle, marrow, and different hypoxic conditions in vitro. Med Sci Monit 2014;20:2171-2176.

8. Li HZ, Chen Z, Hou CL, Tang YX, Wang F, Fu QG. Uric acid promotes osteogenic differentiation and inhibits adipogenic differentiation of human bone mesenchymal stem cells. J Biochem Mol Toxicol 2015;29:382-387.

9. Mohd Ali N, Boo L, Yeap SK, Ky H, Satharasinghe DA, Liew WC, Ong HK, Cheong SK, Kamarul T. Probable impact of age and hypoxia on proliferation and microRNA expression profile of bone marrow-derived human mesenchymal stem cells. Peer J 2016;4:e1536.

10. Gottipamula S, Ashwin KM, Muttigi MS, Kannan S, Kolkundkar U, Seetharam RN. Isolation, expansion and characterization of bone marrowderived mesenchymal stromal cells in serum-free conditions. Cell Tissue Res 2014;356:123-135. 